\title{
A Caries Vaccine?
}

\author{
The State of the Science of Immunization against Dental Caries
}

\author{
Michael W. Russell a Noel K. Childers ${ }^{b}$ Suzanne M. Michalek ${ }^{c}$ \\ Daniel J. Smith ${ }^{d}$ Martin A. Taubmand \\ aDepartments of Oral Biology and Microbiology and Immunology, University at Buffalo, Buffalo, N.Y., \\ Departments of ${ }^{b}$ Oral Biology and ${ }^{c}$ Microbiology, University of Alabama at Birmingham, Birmingham, Ala., and \\ dDepartment of Immunology, Forsyth Institute, Boston, Mass., USA
}

\section{Key Words}

Mutans streptococci · Salivary $\lg \mathrm{A}$ antibodies · Vaccine antigen - Mucosal immunization

\begin{abstract}
Studies performed in numerous laboratories over several decades have demonstrated the feasibility of immunizing experimental rodents or primates with protein antigens derived from Streptococcus mutans or Streptococcus sobrinus against oral colonization by mutans streptococci and the development of dental caries. Protection has been attributed to salivary $\lg A$ antibodies which can inhibit sucrose-independent or sucrose-dependent mechanisms of streptococcal accumulation on tooth surfaces according to the choice of vaccine antigen. Strategies of mucosal immunization have been developed to induce high levels of salivary antibodies that can persist for prolonged periods and to establish immune memory. Studies in humans show that salivary antibodies to mutans streptococci can be induced by similar approaches, and that passively applied antibodies can also suppress oral re-colonization by mutans streptococci. Progress towards practical vaccine development requires evaluation of candidate vaccines in clinical trials. Promising strategies of passive immunization also require further clinical evaluation.
\end{abstract}

Copyright $\odot 2004$ S. Karger AG, Basel
The concept of vaccination against dental caries has existed almost from the time that this disease was recognized to result from colonization of the teeth by acidogenic bacteria, even though the etiological agents were originally thought to be lactobacilli. Since then, Streptococcus mutans and Streptococcus sobrinus and their relatives, collectively known as mutans streptococci, have become recognized as the principal organisms responsible for initiating caries in humans [Loesche, 1986], and considerable progress has been made in elucidating the factors involved in their pathogenic activity, culminating recently in the sequencing of the entire $S$. mutans genome [Ajdic et al., 2002]. Likewise, enormous strides have been made in comprehending the workings of the mucosal immune system by which secretory IgA (S-IgA) antibodies are generated in saliva and other secretions [Ogra et al., 1999]. This system is functional in newborn infants, and although at birth salivary IgA levels are almost zero, infants promptly develop salivary IgA antibodies concomitantly with oral microbial colonization [Smith and Taubman, 1992; Smith et al., 1998]. The mechanisms of action of salivary $\operatorname{IgA}$ antibodies against mutans streptococci include interference with their sucrose-independent and sucrose-dependent attachment to, and accumulation on, tooth surfaces, as well as possible inhibition of their metabolic activities [Russell et al., 1999]. The goal of immunizing infants and young children against colonization by mutans streptococci and hence diminishing the develop-

\begin{tabular}{ll}
\hline KARGER & (c) 2004 S. Karger AG, Basel \\
$\begin{array}{l}\text { Fax + 41 61306 1234 } \\
\text { E-Mail karger@karger.ch } \\
\text { www.karger.com }\end{array}$ & $\begin{array}{l}\text { Accessible online at: } \\
\text { www.karger.com/cre }\end{array}$
\end{tabular}

Michael W. Russell, PhD

Department of Microbiology, Farber 138

University at Buffalo, 3435 Main Street

Buffalo, NY 14214 (USA)

Tel. +1 716829 2790, Fax +1 716829 2169, E-Mail russellm@buffalo.edu 
ment of caries might be accomplished by applying new strategies of mucosal vaccination that would induce salivary IgA antibodies without the complications of parenteral injection. A large body of experimental work over several decades has demonstrated the feasibility of inducing protective immunity against mutans streptococci and the subsequent development of dental caries in animal models. Information has also accrued from several smallscale trials in adult volunteers attesting to the applicability of these approaches to humans. For other recent reviews of this subject, see Childers et al. [2002], Koga et al. [2002], Russell et al. [1999], Russell [2001] and Smith [2002].

\section{Current Approaches and Findings in Active Immunization}

Although over the years numerous surface or secreted products of mutans streptococci have been proposed as vaccine antigen candidates, attention has become focused on three protein antigens: the surface fibrillar adhesins known as AgI/II (synonyms: antigen B, P1, SpaP, PAc, SpaA, PAg), the glucosyltransferases (GTF) and the glucan-binding proteins, all of which have demonstrable associations with virulence and the process of tooth surface colonization [Jenkinson and Lamont, 1997]. While some early efforts utilized parenteral injection which was successful in rodent and primate models [Lehner et al., 1976; Russell et al., 1982] probably because of gingival transudation of circulating antibodies [Challacombe et al., 1978], most authorities have long recognized that mucosal routes of immunization, designed to stimulate the common mucosal immune system and induce potent salivary S-IgA antibodies, will not only be more efficacious but also be more acceptable and circumvent some concerns over safety. This and other vaccine goals have driven the development of novel strategies for effectively stimulating mucosal immune responses [Russell, 2003]. Several of these have been applied to mutans streptococcal antigens, including the delivery of immunogens in liposomes and other microparticles, co-administration of mucosal adjuvants such as enterobacterial enterotoxins and their detoxified mutants, coupling of immunogens to the nontoxic B subunits of enterotoxins and the expression of mutans streptococcal antigens in attenuated Salmonella strains [Eastcott et al., 2002; Hajishengallis et al., 1995; Harokopakis et al., 1997; Huang et al., 2001; Martin et al., 2000; Michalek et al., 1992; Russell and Wu, 1991; Smith et al., 2000]. In addition, molecular engineer- ing of protein antigens by recombinant DNA technology as well as the construction of synthetic peptides representing identified antigenic epitopes have been pursued [Jespersgaard et al., 1999; Smith et al., 2003; Takahashi et al., 1991; Taubman et al., 1995; Zhang et al., 2002].

Numerous experiments in a variety of animal models comprising rodents and primates have demonstrated the induction of salivary S-IgA and circulating IgG antibodies to mutans streptococcal antigens by oral or intranasal immunization with AgI/II, GTF or glucan-binding proteins [reviewed in Childers et al., 2002; Koga et al., 2002; Russell et al., 1999; Russell, 2001; Smith, 2002]. Upon subsequent oral challenge with virulent mutans streptococci and the institution of a high-sucrose diet, these models have further demonstrated reductions in colonization and diminished development of dental caries lesions. Despite these successes, rodent models in particular have limitations in predicting applicability of findings to the human situation for a variety of reasons, including the short duration of the experiments compared with the time scale of caries development in humans. Thus, it is important that the generation of salivary IgA antibodies by immunization procedures developed in rodents has been achieved in primates [Russell et al., 1996] and in human experiments (see below).

An important aspect of mucosal immunity centers around the question of immunological memory and the recall of responses upon subsequent exposure to antigens. Most studies of memory have focused on systemic antibody and cellular responses, and indeed earlier concepts, especially those founded upon experiments using simple methods of oral immunization with killed microorganisms or purified protein antigens, held that memory was poorly developed in the mucosal immune system. More effective strategies of mucosal immunization, especially those exploiting the extraordinary immunogenicity and adjuvanticity of cholera and related enterotoxins, however, have shown that memory can be induced and recalled by mucosal immunization [Harrod et al., 2001; Vajdy and Lycke, 1993]. While many details of the cellular and regulatory mechanisms underlying this remain to be elucidated, this finding has important implications for the development of vaccines against many mucosal infections including caries. Particularly in this case, it may be desirable that a salivary antibody response should be induced and sustained throughout the "window of infectivity', the period from approximately 18 to 32 months of age when infants are most likely to become infected with mutans streptococci [Caufield et al., 1993]. It may also be desirable that responses should be recallable either by 
booster immunization or by natural exposure to mutans streptococci, if further opportunities for infection arise at later times, such as when children enter school or their permanent teeth erupt. Thus, we have found that salivary IgA responses to AgI/II induced by mucosal immunization with $\mathrm{AgI} / \mathrm{II}$ coupled to cholera toxin B subunit or expressed in recombinant Salmonella can persist for up to 1 year in mice (i.e. for half their normal life-span; table 1) and are amenable to prompt recall by booster immunization even after 2 years [Hajishengallis et al., 1996; Harokopakis et al., 1997; Harrod et al., 2001; Russell and Wu, 1991; Wu et al., 2000].

\section{Human Trials}

Several small-scale human trials in adults have shown that it is feasible to increase levels of salivary S-IgA antibodies to mutans streptococci, and in some cases to inter-

Table 1. Persistence of serum and salivary antibodies to AgI/II in mice after intranasal immunization with $\mathrm{AgI} / \mathrm{II}$ conjugated to cholera toxin B subunit

\begin{tabular}{|c|c|c|c|}
\hline \multirow{2}{*}{$\begin{array}{l}\text { Time after } \\
\text { immunization }\end{array}$} & \multicolumn{2}{|l|}{ Serum } & \multirow{2}{*}{$\frac{\text { Saliva }}{\operatorname{IgA}(\mathrm{Ab} / \mathrm{Ig}), \%}$} \\
\hline & $\mathrm{IgG}, \mu \mathrm{g} / \mathrm{ml}$ & $\mathrm{IgA}, \mu \mathrm{g} / \mathrm{ml}$ & \\
\hline Before & $\begin{array}{l}0.25 \\
\times / \div 2.31\end{array}$ & $\begin{array}{l}1.42 \\
\times / \div 1.38\end{array}$ & 0 \\
\hline 4 months & $\begin{array}{l}571 \\
\times / \div 1.84\end{array}$ & $\begin{array}{l}43.1 \\
\times / \div 1.50\end{array}$ & $\begin{array}{l}60.5 \\
\times / \div 1.41\end{array}$ \\
\hline 8 months & $\begin{array}{l}175 \\
\times / \div 1.58\end{array}$ & $\begin{array}{l}16.1 \\
\times / \div 1.69\end{array}$ & $\begin{array}{l}13.6 \\
\times / \div 1.76\end{array}$ \\
\hline 12 months & $\begin{array}{l}136 \\
\times / \div 1.83\end{array}$ & $\begin{array}{l}24.2 \\
\times / \div 1.40\end{array}$ & $\begin{array}{l}21.6 \\
\times / \div 1.54\end{array}$ \\
\hline
\end{tabular}

Geometric mean $\times / \div \mathrm{SD}, \mathrm{n}=5$; from $\mathrm{Wu}$ et al. [2000]. fere with mutans streptococcal colonization (table 2). Human volunteers immunized orally with $S$. sobrinus GTF packaged in enteric capsules (14 young adults, compared with 11 placebo controls) developed increased levels of parotid salivary IgA antibodies to GTF and showed delayed reaccumulation of mutans streptococci in their oral microbiota [Smith and Taubman, 1987]. In a further study on 23 young adults, topical application of GTF to the lower lip intended to stimulate local antibody production in the minor salivary glands also delayed oral recolonization with mutans streptococci although antibody levels were not significantly increased [Smith and Taubman, 1990]. Oral immunization with preparations of $S$. mutans GTF that also contained a truncated form of AgI/ II in enteric capsules was also successful in elevating salivary IgA antibodies to the antigen preparation [Childers et al., 1994]. When similar antigen preparations were administered intranasally or by topical application to the tonsils, either in soluble form or incorporated in liposomes, salivary IgA antibodies were likewise increased [Childers et al., 1997, 1999, 2002, 2003; Li et al., 2003]. These studies now need to be extended into progressively younger age groups in controlled trials aimed at establishing whether equivalent responses can be induced in children and whether the responses obtained can suppress oral colonization by mutans streptococci.

\section{Passive Immunization - An Alternative Approach}

An alternative approach lies in the development of antibodies suitable for passive oral application against dental caries. This has considerable potential advantage in that it completely avoids any risks that might arise from active immunization. Conversely, in the absence of any active response on the part of the recipient, there is no

Table 2. Trials in adult humans: active immunization with $S$. mutans protein antigens

\begin{tabular}{|c|c|c|c|c|}
\hline Antigen & Route & $\mathrm{n}$ & Predominant antibody response (protective effect) & Reference \\
\hline \multirow[t]{2}{*}{ GTF } & oral & 25 & $\begin{array}{l}\text { increased salivary IgA antibody } \\
\text { (delayed reaccumulation of indigenous } S . \text { mutans) }\end{array}$ & Smith and Taubman [1987] \\
\hline & topical (MSG) & 23 & (delayed reaccumulation of indigenous $S$. mutans) & Smith and Taubman [1990] \\
\hline GTF & oral & 7 & increased salivary IgA2 antibody (n.t.) & Childers et al. [1994] \\
\hline \multirow[t]{4}{*}{$(+\mathrm{AgI} / \mathrm{II})$} & nasal & 5,21 & increased nasal IgA1, salivary IgA1 and IgA2 antibodies (n.t.) & Childers et al. [1997, 1999] \\
\hline & nasal or tonsillar (topical) & 21 & IgA1 nasal and salivary antibodies in nasal group (n.t.) & Childers et al. [2002] \\
\hline & nasal & 12 & salivary IgA1 antibodies (n.t.) & Li et al. [2003] \\
\hline & nasal & 26 & IgA1 nasal and salivary antibodies (n.t.) & Childers et al. [2003] \\
\hline
\end{tabular}

MSG $=$ Minor salivary glands $;$ n.t. $=$ not tested. 
induction of immunological memory, and the administered antibodies can persist in the mouth for only a few hours at most or up to 3 days in plaque [Ma et al., 1990]. Strategies include the development of antibodies to mutans streptococcal antigens in cow's milk and hen's eggs and the genetic engineering of human-like S-IgA antibodies in plants [Hamada et al., 1991; Hatta et al., 1997; Loimaranta et al., 1998; Ma et al., 1995; Mitoma et al., 2002]. Animal experiments have been encouraging: for example, the administration of chicken egg IgY antibodies to glucan-binding proteins diminished the development of caries lesions in a rat model [Smith et al., 2001]. Mouse monoclonal antibodies to AgI/II applied topically inhibited oral colonization by mutans streptococci and development of caries in monkeys for at least 1 year [Lehner et al., 1985]. Similar treatment, after extensive oral prophylaxis, of a small number of human adult volunteers with this IgG, or with engineered 'human' SIgA antibodies derived from the same monoclonal antibody, also suppressed the re-emergence of mutans streptococci for up to 2 years or 4 months, respectively [Ma et al., 1990, 1998]. The plausible though unproven explanation offered for these findings was that once mutans streptococci had been displaced by prophylaxis, passive application of antibody prevented their immediate re-colonization so that their oral 'niche' became occupied by other species with the result that their re-emergence was suppressed for far longer than the antibody persisted in the mouth. Unfortunately, further experiments on larger numbers of adults have not consistently demonstrated equivalent long-term reductions in colonization [Weintraub et al., 2001]. Whether a similar application of antibodies to young infants might inhibit subsequent oral colonization by mutans streptococci remains to be determined. However, in spite of these disappointments, collectively these studies clearly demonstrate the potential of antibodies to interfere with the ability of mutans streptococci to colonize teeth and to inhibit caries development.

The key question then becomes: how can such antibodies be effectively delivered orally in caries-susceptible individuals and maintained at a protective level for the required length of time? Active vaccination has the advantage of inducing the endogenous production of salivary antibodies and the establishment of immune memory but requires a commitment to performing the human trials necessary to establish safety and efficacy. Passive administration of preformed exogenous antibodies offers the advantage of evading risks, however small, that are inherent in any active immunization procedure, but the need to provide a continuous source of antibodies to maintain protection over a prolonged time remains a major challenge. Although new technologies for antibody engineering and production in animals or especially in plants ('plantibodies') offer the prospect of reducing the costs sufficiently to enable these materials to be incorporated into products for daily use, such as mouthwashes and dentifrices, long-term efficacy has yet to be reliably demonstrated.

\section{Future Prospects and Potential Impact}

Given that dental caries usually develops slowly and can occur throughout life, it may be anticipated that immune protection would need to be similarly long-lasting. Thus, the duration and anamnestic recall of salivary antibody responses are important factors. While it is now clear that mucosal immune responses can persist and that memory is established if the priming stimulus is sufficient, relatively little is known about the parameters that govern memory in the mucosal immune system. The characteristics of specific mucosal memory cells, their location, and how they can be recalled and directed to particular effector sites such as the salivary glands to produce IgA antibodies for transport into the secretion are important subjects for investigation. Although current understanding holds that oral colonization with mutans streptococci mainly occurs during a 'window of infectivity' at around 2 years of age after primary teeth begin to erupt, it is unclear whether further opportunities for colonization exist, for example when children enter school and mix socially with a much larger group of their peers, or when the permanent teeth erupt. Two corollaries arise from such considerations: (i) that it would be necessary to immunize infants or young children in order to provide immune protection prior to initial colonization with mutans streptococci; (ii) that booster immunization to recall responses might be desirable to forestall colonization at later time points. As the transmission of mutans streptococci appears to be primarily from mother to infant [ $\mathrm{Li}$ and Caufield, 1995], a third possibility is that young mothers might be immunized actively or passively with the objective of reducing their oral load of mutans streptococci (possibly in combination with conventional prophylaxis or other interventions), thereby diminishing the probability and extent of transmission to their infants. If the transferred bacteria are coated with maternal salivary antibodies, this would likely reduce their capacity to colonize the infant's mouth. It has been suggested that immunization of young mothers to induce the generation 
of antibodies to mutans streptococcci in breast-milk could be exploited to provide passive immunity against caries to their infants. However, it seems unlikely that this strategy would have significant impact at least in Western societies, where breast-feeding, if given, usually terminates well before the 'window of infectivity' for mutans streptococci opens.

Regardless of the mechanism by which immune protection against dental caries is achieved, further advances to make immunization against caries practicable will depend upon clinical trials aimed at establishing whether the findings from animal experiments can be transferred to humans. Particular goals for such studies include determining whether appropriate immune responses can be safely generated in humans, especially in the susceptible age groups, and whether such responses will afford desirable levels of protection.

The goals for vaccination against most other, mainly acute, infectious diseases are usually to provide near-complete protection of the individual against infection, and to achieve a sufficiently high prevalence of immunity in a population that the chain of transmission is broken and the pathogen cannot sustain itself in the community. However, the biology of caries is different from that of acute infections, and as with other modalities of intervention, it is conceivable that immunization will not attain complete effectiveness. Nevertheless, efficacy as low as $50 \%$ could have significant impact on the burden of disease, and the social and economic costs associated with it. Given that the bulk of dental caries occurs among a highrisk sector of the population (at least in the USA), targeting an effective vaccine to such individuals would increase its impact.

\section{Acknowledgements}

The authors' studies have been supported by USPHS grants DE06746, DE09846, DE07026, DE08182, DE09081, DE04733 and DE06153 from the National Institute of Dental and Craniofacial Research.

\section{References}

Ajdic D, McShan WM, McLaughlin RE, Savic G, Chang J, Carson MB, Primeaux C, Tian RY, Kenton S, Jia HG, Lin SP, Qian YD, Li SL, Zhu H, Najar F, Lai HS, White J, Roe BA, Ferretti JJ: Genome sequence of Streptococcus mutans UA159, a cariogenic dental pathogen. Proc Natl Acad Sci USA 2002;99:1443414439.

Caufield P, Cutter G, Dasanayake A: Initial acquisition of mutans streptococci by infants: Evidence for a discrete window of infectivity. $\mathrm{J}$ Dent Res 1993;72:37-45.

Challacombe SJ, Russell MW, Hawkes JE, Bergmeier LA, Lehner T: Passage of immunoglobulins from plasma to the oral cavity in rhesus monkeys. Immunology 1978;35:923-931.

Childers NK, Li F, Kirk K, Dasanayake AP, Kim J-G, Michalek SM: Nasal but not tonsillar immunization of humans with Streptococcus mutans antigens primes for responses 2 years after an initial immunization (abstract 1721). J Dent Res 2003;82(special issue).

Childers NK, Tong G, Li F, Dasanayake AP, Kirk K, Michalek SM: Humans immunized with Streptococcus mutans antigens by mucosal routes. J Dent Res 2002;81:48-52.

Childers NK, Tong G, Michalek SM: Nasal immunization of humans with dehydrated liposomes containing Streptococcus mutans antigen. Oral Microbiol Immunol 1997;12:329-335.
Childers NK, Tong G, Mitchell S, Kirk K, Russell MW, Michalek SM: A controlled clinical study of the effect of nasal immunization with a Streptococcus mutans antigen alone or incorporated into liposomes on induction of immune responses. Infect Immun 1999;67:618-623.

Childers NK, Zhang SS, Michalek SM: Oral immunization of humans with dehydrated liposomes containing Streptococcus mutans glucosyltransferase induces salivary immunoglobulin A2 antibody responses. Oral Microbiol Immunol 1994;9:146-153.

Eastcott JW, Orr N, Smith DJ, Hayden TL, Taubman MA: Expression and delivery of GTF peptides in Salmonella enterica (abstract 3886). J Dent Res 2002;81(special issue A).

Hajishengallis G, Hollingshead SK, Koga T, Russell MW: Mucosal immunization with a bacterial protein antigen genetically coupled to cholera toxin A2/B subunits. J Immunol 1995;154: 4322-4332.

Hajishengallis G, Michalek SM, Russell MW: Persistence of serum and salivary antibody responses after oral immunization with a bacterial protein antigen genetically linked to the A2/B subunits of cholera toxin. Infect Immun 1996;64:665-667.

Hamada S, Horikoshi T, Minami T, Kawabata S, Hiraoka J, Fujiwara T, Ooshima T: Oral passive immunization against dental caries in rats by use of hen egg yolk antibodies specific for cell-associated glucosyltransferase of Streptococcus mutans. Infect Immun 1991;59:41614167.
Harokopakis E, Hajishengallis G, Greenway TE, Russell MW, Michalek SM: Mucosal immunogenicity of a recombinant Salmonella typhimurium-cloned heterologous antigen in the absence or presence of co-expressed cholera toxin A2/B subunits. Infect Immun 1997;65:14451454.

Harrod T, Martin M, Russell MW: Long-term persistence and recall of immune responses in aged mice after mucosal immunization. Oral Microbiol Immunol 2001;16:170-177.

Hatta H, Tsuda K, Ozeki M, Kim M, Yamamoto T, Otake S, Hirasawa M, Katz J, Childers NK, Michalek SM: Passive immunization against dental plaque formation in humans: Effect of a mouth rinse containing egg yolk antibodies (IgY) specific to Streptococcus mutans. Caries Res 1997;31:268-274.

Huang Y, Hajishengallis G, Michalek SM: Induction of protective immunity against Streptococcus mutans colonization after mucosal immunization with attenuated Salmonella enterica serovar typhimurium expressing an S. mutans adhesin under the control of in vivo-inducible nirB promoter. Infect Immun 2001;69:2154 2161.

Jenkinson HF, Lamont RJ: Streptococcal adhesion and colonization. Crit Rev Oral Biol Med 1997;8:175-200. 
Jespersgaard C, Hajishengallis G, Huang Y, Russell MW, Smith DJ, Michalek SM: Protective immunity against Streptococcus mutans infection in mice after intranasal immunization with the glucan-binding region of S. mutans glucosyltransferase. Infect Immun 1999;67:65436549.

Koga T, Oho T, Shimazaki Y, Nakano Y: Immunization against dental caries. Vaccine 2002;20: 2027-2044

Lehner T, Caldwell J, Smith R: Local passive immunization by monoclonal antibodies against streptococcal antigen I/II in the prevention of dental caries. Infect Immun 1985;50:796-799.

Lehner T, Challacombe SJ, Caldwell J: Immunological basis for vaccination against dental caries in rhesus monkeys. J Dent Res 1976;55(special issue C): 166 .

Li F, Michalek SM, Dasanayake AP, Li Y, Kirk K, Childers NK: Intranasal immunization of humans with Streptococcus mutans antigens: Low dose differentiates responses to soluble versus liposomal antigens. Oral Microbiol Immunol 2003; 18:271-277

Li Y, Caufield PW: The fidelity of initial acquisition of mutans streptococci by infants from their mothers. J Dent Res 1995;74:681-685.

Loesche WJ: Role of Streptococcus mutans in human dental decay. Microbiol Rev 1986;50: 353-380.

Loimaranta V, Carlén A, Olsson J, Tenovuo J, Syväoja EL, Korhonen H: Concentrated bovine colostral whey proteins from Streptococcus mutans/Strep. sobrinus immunized cows inhibit the adherence of Strep. mutans and promote the aggregation of mutans streptococci. J Dairy Res 1998;65:599-607.

Ma JKC, Hiatt A, Hein M, Vine ND, Wang F, Stabila P, Van Dolleweerd C, Mostov K, Lehner $\mathrm{T}$ : Generation and assembly of secretory antibodies in plants. Science 1995;268:716-719.

Ma JKC, Hikmat BY, Wycoff K, Vine ND, Chargelegue D, Yu L, Hein MB, Lehner T: Characterization of a recombinant plant monoclonal secretory antibody and preventive immunotherapy in humans. Nat Med 1998;4:601-606.

Ma JKC, Hunjan M, Smith R, Kelly C, Lehner T: An investigation into the mechanism of protection by local passive immunization with monoclonal antibodies against Streptococcus mutans Infect Immun 1990;58:3407-3414.

Martin MH, Metzger DJ, Michalek SM, Connell TD, Russell MW: Comparative analysis of the mucosal adjuvanticity of the type II heat-labile enterotoxins, LT-IIa and LT-IIb. Infect Immun 2000;68:281-287.
Michalek SM, Childers NK, Katz J, Dertzbaugh M, Zhang S, Russell MW, Macrina FL, Jackson S, Mestecky J: Liposomes and conjugate vaccines for antigen delivery and induction of mucosal immune responses. Adv Exp Med Biol 1992; 327:191-198.

Mitoma M, Oho T, Michibata N, Okano K, Nakano Y, Fukuyama M, Koga T: Passive immunization with bovine milk containing antibodies to a cell surface protein antigen-glucosyltransferase fusion protein protects rats against dental caries. Infect Immun 2002;70:2721-2724.

Ogra PL, Mestecky J, Lamm ME, Strober W, Bienenstock J, McGhee JR (eds): Mucosal Immunology. San Diego, Academic Press, 1999.

Russell MW: Potential for vaccines in the prevention of caries lesions. Oper Dent 2001;suppl 6:51-60.

Russell MW: Mucosal immunity; in Ellis RW, Brodeur BR (eds): New Bacterial Vaccines. Georgetown, Landes Bioscience, 2003.

Russell MW, Hajishengallis G, Childers NK, Michalek SM: Secretory immunity in defense against cariogenic mutans streptococci. Caries Res 1999;33:4-15

Russell MW, Moldoveanu Z, White PL, Sibert GJ, Mestecky J, Michalek SM: Salivary, nasal, genital, and systemic antibody responses in monkeys immunized intranasally with a bacterial protein antigen and the cholera toxin B subunit. Infect Immun 1996;64:1272-1283.

Russell MW, Wu H-Y: Distribution, persistence, and recall of serum and salivary antibody responses to peroral immunization with protein antigen I/II of Streptococcus mutans coupled to the cholera toxin B subunit. Infect Immun 1991;59:4061-4070.

Russell RRB, Beighton D, Cohen B: Immunization of monkeys (Macaca fascicularis) with antigens purified from Streptococcus mutans. Br Dent J 1982;152:81-84.

Smith DJ: Dental caries vaccines: Prospects and concerns. Crit Rev Oral Biol Med 2002;13: 335-349.

Smith DJ, King WF, Akita H, Taubman MA: Association of salivary immunoglobulin A antibody and initial mutans streptococcal infection. Oral Microbiol Immunol 1998;13:278-285.

Smith DJ, King WF, Barnes LA, Peacock Z, Taubman MA: Immunogenicity and protective immunity induced by synthetic peptides associated with putative immunodominant regions of Streptococcus mutans glucan-binding protein B. Infect Immun 2003;71:1179-1184.

Smith DJ, King WF, Godiska R: Passive transfer of immunoglobulin Y antibody to Streptococcus mutans glucan binding protein B can confer protection against experimental dental caries. Infect Immun 2001;69:3135-3142.
Smith DJ, Taubman MA: Oral immunization of humans with Streptococcus sobrinus glucosyltransferase. Infect Immun 1987;55:25622569.

Smith DJ, Taubman MA: Effect of local deposition of antigen on salivary immune responses and reaccumulation of mutans streptococci. J Clin Immunol 1990;10:273-281.

Smith DJ, Taubman MA: Ontogeny of immunity to oral microbiota in humans. Crit Rev Oral Biol Med 1992;3:109-133.

Smith DJ, Trantolo DJ, King WF, Gusek EJ, Fackler PH, Gresser JD, De Souza VL, Wise DL: Induction of secretory immunity with bioadhesive poly $(D, L$-lactide-co-glycolide) microparticles containing Streptococcus sobrinus glucosyltransferase. Oral Microbiol Immunol 2000;15: 124-130.

Takahashi I, Okahashi N, Matsushita K, Tokuda M, Kanamoto T, Munekata E, Russell MW, Koga T: Immunogenicity and protective effect against oral colonization by Streptococcus mutans of synthetic peptides of a streptococcal surface protein antigen. J Immunol 1991;146: 332-336.

Taubman MA, Holmberg CJ, Smith DJ: Immunization of rats with synthetic peptide constructs from the glucan-binding or catalytic region of mutans streptococcal glucosyltransferase protects against dental caries. Infect Immun 1995; 63:3088-3093.

Vajdy M, Lycke N: Stimulation of antigen-specific $\mathrm{T}$ - and B-cell memory in local as well as systemic lymphoid tissues following oral immunization with cholera toxin adjuvant. Immunology 1993;80:197-203.

Weintraub JA, Hilton JF, White JM, Hoover C, Pelino JE, Tran K, Wycoff K, Larrick JW, Yu L, Featherstone JDB: Results of a plant-derived mutans streptococci antibody clinical trial (abstract 201). J Dent Res 2001;80(special issue).

Wu HY, Abdu S, Stinson D, Russell MW: Generation of female genital tract antibody responses by local or central (common) mucosal immunization. Infect Immun 2000;68:5539-5545.

Zhang P, Jespersgaard C, Lamberty-Mallory L, Katz J, Huang Y, Hajishengallis G, Michalek SM: Enhanced immunogenicity of a genetic chimeric protein consisting of two virulence antigens of Streptococcus mutans and protection against infection. Infect Immun 2002; 70: 6779-6787. 